\title{
STATUS OF THE OPERATOR'S LIEN IN LAW AND IN EQUITY
}

\author{
KAREN L. PETTIFER*
}

\begin{abstract}
This paper examines the Operator's lien, as it is written in the 1981 Canadian Association of Petroleum Landmen Operating Procedure, and the law of Canada, the Commonwealth and the United States to determine the nature of the Operator's interest and the steps which the Operator must take to perfect its security and succeed in priority contests with other creditors.
\end{abstract}

\section{THE OPERATING AGREEMENT}

The Canadian Association of Petroleum Landmen ("CAPL") has developed four standard-form Operating Agreements since 1969 to govern the legal relationship between Joint-Operators who have participating interests in the petroleum substances leased from either private owners or the Crown. The Agreement is designed to supplement a basic contract among the parties which may address matters such as drilling obligations. ${ }^{1}$ It is the Operating Agreement which eventually governs day-to-day operations, including activities such as the drilling, completing, equipping and operating of joint interest wells.

The most recent standard-form CAPL Agreement was drafted in 1981 and is used frequently by the industry. Article XV of the Agreement defines the relationship of the parties as tenants in common and not as creating a partnership, joint venture or association. ${ }^{2}$ The Joint-Operators collectively agree to appoint one party as the Operator to carry out operations "for the joint account", which means ". . . for the benefit, interest, ownership, risk, cost, expense and obligation of the parties hereto in proportion to each party's participating interest". ${ }^{3}$ The Operator is granted the control and management of the operation of the joint lands. ${ }^{4}$ Expenditures made by the Operator for the joint account are limited to a total estimated cost of $\$ 25,000$ unless there is a written Authority for Expenditure ("AFE") from the Joint-Operators or the expenditure is necessary by reason of an event endangering life or property. The AFE may be exceeded by no more than ten per cent unless a further authorization is granted. ${ }^{3}$ The Agreement specifies several instances where the Operator has a positive obligation to make expenditures, such as furnishing all of the material, labour and services necessary for operations and paying all accounts of contractors and claims for wages and salaries as they become due. ${ }^{6}$ Article V, clause 502 imposes an obligation on the Operator to initially advance and pay all costs and expenses of operations and to charge each Joint-Operator its proportionate share of such costs and expenses which become due thirty days

- Student-At-Law, Burnet, Duckworth and Palmer, Calgary, Alberta. This paper was the recipient of the 1986 Canadian Petroleum Law Foundation Essay Prize.

1. Boyer, "The 1981 CAPL Operating Procedure" (1983) XXI Alta. L. Rev. at 82.

2. The legal validity of this characterization would depend on whether the parties created a joint tenancy in law.

3. Canadian Association of Petroleum Landmen, "Operating Procedure: 1981" Art. I, cl. 101(i).

4. Id. at Art. III, cl. 301

5. Id.

6. Id. at Art. III, cls. 303 and 306. 
thereafter. This clause is, however, made subject to clause 503 which allows the Operator to elect to require each Joint-Operator to advance its proportionate share of all costs and expenses to be incurred for the joint account. While this self-help remedy would usually afford the Operator the protection he requires against the failure of a Joint-Operator to contribute its proportionate share, it is unrealistic to assume that all of the expenses incurred by the Operator will be anticipated or requested in advance. To deal with this eventuality, the Operator is given several remedies, including: the Operator's lien; an assignment of the defaulting party's proceeds of sale; and a right to collect the amount owed by one Joint-Operator from the others if payment has been due for three months.' The contributors are proportionately subrogated to the Operator's rights pursuant to his lien. The following is the full text of the Operator's lien:

505 OPERATOR'S LIEN

a. The Operator shall have a lien on the interest of each Joint-Operator in the joint lands and in production, wells and equipment therefrom and thereon to secure payment of each Joint-Operator's proportionate share of the cost and expense of all operations carried on by the Operator for the joint account.

b. If a Joint-Operator fails to pay or advance any of the costs hereby agreed to be paid or advanced by it, and the default continues for thirty (30) days after the Operator has served notice upon the Joint-Operator specifying the default and requiring the same to be remedied, the Operator may, without limiting the Operator's other rights at law:

i. withhold from such Joint-Operator any further information and privileges with respect to operations;

ii. treat the default as an immediate and automatic assignment to the Operator of the proceeds of the sale of such Joint-Operator's share of the petroleum substances; and from and after the Operator making such election, the Operator may require the purchaser of such Joint-Operator's share of the petroleum substances to make payment therefor to the Operator while the default continues; and

iii. enforce the lien created by the default in payment by taking possession of all or any part of the interest of the defaulting Joint-Operator in the joint lands or in all or any part of the production therefrom and equipment thereon; and the Operator may sell and dispose of any interest, production or equipment of which it has so taken possession either in whole or in part or in separate parcels at public auction or by private tender at a time and on whatever terms it shall arrange, having first given notice to the defaulting Joint-Operaor of the time and place of the sale. The proceeds of the sale shall be first applied by the Operator in payment of any costs to be paid by the defaulting Joint-Operator and not paid by it and any balance remaining shall be paid to the defaulting Joint-Operator after deducting reasonable costs of the sale. Any sale made as aforesaid shall be a perpetual bar both at law and in equity against the defaulting Joint-Operator and its assigns and against all other persons claiming the property or any part or parcel thereof sold as aforesaid by, from, through or under the defaulting Joint-Operator or its assigns.

In addition to the express remedies granted to the Operator, an action for breach of contract could be maintained against any defaulting party.

The frequent use of contractual liens in the petroleum industry and other industries has resulted, only infrequently, in litigation in Canada and there has been virtually no consideration by other authors of the legal status of contractual liens in Canada or the United Kingdom. ${ }^{8}$ Several American

7. Id. at Art. V, cls. 505 and 506.

8. R.M.H., "Lien and the Right of Sale" 96 S.J. 84; Sunnuks, "Lord Thurlow's Equity or a Cuckoo in the Legal Nest" (1970) 33 Mod. L.R. 131; Peden, "The Creation of Common Law Liens" (1969) 18 I.C.L.Q. 129; Adams, "Purchase Money and Liens" (1969) 113 S.J. 65. 
writers have considered the contractual lien provided for in the American Association of Petroleum Landmen Model Form Operating Agreement (1977) ("AAPL") and the American courts have considered that particular clause. The utility of these sources may be limited, however, as a result of the legal characterization of the contractual lien in American law, which is significantly different than the traditional position taken by the United Kingdom and other Commonwealth countries, including Canada.

In order to determine the effectiveness of the contractual lien in securing the interest of the Operator for the amounts owing from the JointOperators, a review of the legal status of the contractual lien in respect of personalty and realty will be undertaken. In this regard, it is necessary to distinguish between liens arising by the operation of law and liens arising by agreement between the parties. Both categories of lien will be considered to obtain a more complete picture of the nature of a lien generally, however, there are significant differences between them. The contractual lien creates either a mere possessory interest or an interest in the property that attracts registration requirements which, if not complied with, would render the lien void as against certain creditors. Clause 505 of the CAPL Agreement must be classified in the light of the case law as either a possessory interest or an interest in the property, and the conclusion drawn will determine the registration requirement for the lien, if any, and the outcome of a priority contest between the Operator's lien and other forms of security.

\section{THE STATUS OF CONTRACTUAL LIENS IN LAW AND IN EQUITY}

In the absence of a contractual promise to grant a lien, no lien arises when one person expends money on the property of another thereby improving the property, even if the person incurring the expense has an interest in the property. ${ }^{9}$ In the same light, a tenant in common has no lien against the share of his co-tenant for payments made for the benefit of the estate. ${ }^{10}$ This principle has been authoritatively decided for Canadian law in Ruptash v. Zawick," wherein Cartwright J. speaking for the Supreme Court of Canada decided as follows: ${ }^{12}$

In my opinion, apart from contract the right of a tenant in common who has made repairs to the property of which his co-tenant has taken the benefit is limited to an equitable right to an accounting which can be asserted only in a suit for partition; he does not acquire a lien or charge on the property itself.

It does not follow, however, that a lien may not arise by the operation of law or equity or by the express terms of the contract.

The word "lien" is a nebulous term which is used inconsistently by the Courts and writers to describe a variety of interests. In its simplest form, it is a legal right of one person to retain an item of property which is rightfully and continuously in his possession until the owner satisfies the debt owed

9. Burridge v. Row (1842) I Y \& C Ch. Cas. 183; Wallis v. Smith (1882) 21 Ch. D. 243, cited in Halsbury's Laws of England, 4th Ed., Vol. 28 at 246.

10. Exparte Young (1893) 2 Ves. \& B. 242; Re Wicholson (1813) 2 Rose 76 in Halsbury's supran. 9 at 253.

11. [1956] S.C.R. 347 revg. (1955) 15 W.W.R. 518, [1955] 4 D.L.R. 195 (Alta. S.C.A.D.).

12. Id. [1956] S.C.R. 347 at 361. 
in respect of that property. This right may be conferred by law or by contract. ${ }^{13}$ The right to a lien has also been characterized as an equitable interest in the property which is conferred either by the operation of equity or by express agreement. Still other Courts and writers have described the deposit of property to secure a debt as a pledge or even a mortgage. These categories are overlapping and are used inconsistently to describe the type of interest held by one who has possession or perhaps a right to possession as security for a debt. A comparison of these categories and their attendant rights and consequences will be undertaken.

The most important distinction is between a common law lien and an equitable lien. It is stated in Snell's Principles of Equity in the following manner: $:^{14}$
a. Legal Lien. A common law lien is the right to retain possession of the goods of another until his claims are satisfied. It depends upon possession, and so lasts only as long as possession is retained; but while it exists it is good against the whole world. Formerly, such a lien gave no right to sell the property, although the court had a discretionary power to authorize a sale.
b. Equitable Lien. An equitable lien is very different. It confers a charge upon property until certain claims are satisfied, and differs from an equitable charge only in that it arises by operation of equity from the relationship between the parties rather than by act of parties. It exists independently of possession, but will not avail against a purchaser for value of a legal estate without notice of it. It is enforceable by means of an order for sale.

The common law lien is possessory only, with no interest in the property possessed. It subsists only as long as possession and is an unassignable personal right. ${ }^{15}$ Such a lien will be particular rather than general except in certain circumstances.16 The particular lien is based on the right to retain goods for which charges have been incurred until those specific charges have been paid, but not until the charges on the general account are paid. The latter is a general lien which entitles a person in possession of chattels to retain them until the entire account is paid rather than simply the debt owed in respect of the particular goods held. ${ }^{17}$ A general lien is said to arise either by a general trade usage or by express agreement. ${ }^{18} \mathrm{~A}$ trade usage must be certain and reasonable and so universally acquiesced in that everyone in the trade knew of, or could have ascertained, its existence. ${ }^{19}$ If there is evidence of numerous and important instances of the usage, the parties are presumed to be aware of and bound by the usage.

Extinction of a legal lien may occur by reason of tender, abandonment, the taking of alternative security or an inconsistent course of dealing, ${ }^{20}$ loss

13. Halsbury's, supra n. 9 at 227.

14. Snell's Principles of Equity (1966 26th Ed.) at 482.

15. Halsbury's, supra n. 9 at 225 ; Legg v. Evans 6 M. \& W. 36.

16. Webster, Ashburner On Mortgages, (1911 2nd Ed.) at 81.

17. Halsbury's, supra n. 9 at 227.

18. By express agreement: Kircher v. Venus (1859) 12 Mos. P.C.C. 361; Jewitt \& Sons v. Union Cold Storage Co. [1913] 3 K.B. 1; U.S. Steel Products Co. v. Great Western Railway Co. [1916] 1 A.C. 189; Re Southern Livestock Producers [1963] 3 All E.R. 801.

19. Plaice v. Alock (1866) 4 F. \& F. 1074.

20. Re King (1924) 4 C.B.R. 688, 26 O.W.N. 392, 424. 
of possession, receivership or bankruptcy. ${ }^{21}$ There will be no right of sale ${ }^{22}$ unless the contract provides so expressly.

An equitable lien arises by the operation of equity, on the basis of principles such as equity regards as done that which ought to be done, or by express contract. ${ }^{23}$ Unlike the common law lien, the equitable lien is not based on possession and is assignable. A good example is the unpaid vendor's lien which arises in equity at the time of the conveyance of real property, giving the vendor an interest in the property until the balance is paid. ${ }^{24}$ An equitable lien will likely be a registrable instrument as an interest in realty or personalty depending on the specific statutory requirements of each jurisdiction. Such a lien is enforceable by a judicial sale $e^{25}$ or a private sale if that right is granted by contract. ${ }^{26}$ There is some Canadian authority to suggest that a private sale must be carried out in good faith and not "fraudulently, wilfully or recklessly" such as selling at a depressed price ${ }^{27}$ and prior notice of the sale must be given to the debtor. ${ }^{28}$ It is reasonable to question whether a person exercising a right of sale today would be well advised to use the judicial sale process given what can be onerous fiduciary obligations in the situation of a private sale. ${ }^{29}$

There is limited authority to suggest that an equitable lien, like a common law lien, may be either particular or general..$^{30}$ However, the leading textbook writers and cases do not draw this distinction in the case of an equitable lien, depending instead on the extent of the lien in equity or by contract.

In an attempt to reconcile conflicting case law, writers draw distinctions between those charges created by an equitable lien and those created by a legal or equitable mortage. It is generally accepted that "... every charge is not an equitable mortgage though every equitable mortgage is a charge". ${ }^{31}$ Ashburner classifies mortgages as an agreement to transfer property or an actual transfer, whereas an agreement to charge property immediately or in the future without an actual transfer of the property at law, would constitute an equitable charge but not a mortgage. ${ }^{32}$ The primary differ-

21. Halsbury's, supra n. 9 at 243.

22. Pothonier and Hodgson v. Dawson (1816) Holt N.P. 383; Buchan v. Newell(1913)29 O.L.R. 508, 15 D.L.R. 437 (C.A.).

23. Ashburner, Principles of Equity (1933 2nd Ed.) at 248.

24. Re Birmingham [1959] Ch. 523; for other examples of the same principle see: Legard v. Hodges (1792) 29 E.R. 684 (Ch); Swiss Bank Ltd. v. Lloyds Bank infra n. 35 in relation to a charge other than a mortgage which is considered by many to incorporate an equitable lien; Re Crossman, Salaman v. Crossman [1939] 2 All E.R. 530 (Ch.); Whiteside v. Rocky Mountain Fuel 101 F. 2d 765 (10th Cir., 1938).

25. Hope v. Booth (1830) I B. \& Ad. 498, 109 E.R. 872; Munns v. Isle of Wright Railway Co. (1870) 5 Ch. App. 414 (C.A. in Chancery).

26. Pothonier and Hodgson v. Dawson supran. 22; Gurnell v. Gardner (1863) 66 E.R. 857 (H.C. of Chancery).

27. Zess v. Smith [1920] 3 W.W.R. 836, 13 Sask. L.R. 501, 55 D.L.R. 116 (K.B.). Quaere whether this case is limited in principle to a pledgee.

28. Prete v. Lauzon and Fenson (1923) 52 O.L.R. 334 (Ont. S.C.A.D.).

29. Fisher and Lightwood's, Law of Mortgage (1977 9th Ed.) at 367 and 368.

30. Gladstone v. Birley (1817) 2 Mer. 401,35 E.R. 993 (Ch.).

31. Shea v. Moore [1894] 1 I.R. 158 at 168 per Walker C. in the Irish C.A.

32. Supra n. 23 at 251. 
ence is in the remedy, since only a mortgage attracts the right to foreclosure proceedings, ${ }^{33}$ the equitable charge being limited to a judicial sale or a private sale if provided for by contract. The terms equitable charge and equitable lien are used synonymously. ${ }^{34}$

In Swiss Bank Corporation v. Lloyds Bank Ltd. ${ }^{35}$ the plaintiff was asserting an equitable mortgage which was said to arise out of a positive contractual obligation by the debtor to repay a loan primarily out of the fruits of the loan. The Court of Appeal acknowledged that the argument was directed at the existence of an equitable mortgage and referred to the necessity of distinguishing in some future case between an equitable mortgage and an equitable charge. The Court cited Fisher and Lightwood's Law of Mortgage 9th ed. (1977) at pages 13 and 14 for the following propositions. An equitable mortgage is created when the legal owner of property enters into some instrument or does some act which is not sufficient to confer a legal estate to the mortgagee but, nevertheless, demonstrates a binding intention to create a security in favour of the mortgagee. The same authors describe an equitable charge, other than an equitable mortgage, as a charge created when property is expressly or constructively made liable to the discharge of a debt or some other obligation and confers a right of realization by judicial sale. The Court questioned whether something less than an equitable mortgage continues to exist in equity, and then proceeded to conclude that the contract in question did not constitute either an equitable mortgage or an equitable charge. The Court reasoned that the clause in question was incapable on its true construction of constituting any security or creating any equitable charge. The Court followed a decision of the House of Lords wherein the following proposition of law was adopted: $:^{36}$

This is but an instance of a familiar doctrine of equity that a contract for valuable consideration to transfer or charge a subject matter passes a beneficial interest by way of property in that subject matter if the contract is one which a court of equity will decree specific performance.

The Court of Appeal stated that a contract is specifically enforceable if it is an obligation for which damages would be insufficient. Moreover, the Court suggested that a contract to mortgage property, real or personal, would normally be specifically enforceable because a claim to damages alone would be less valuable than a security interest in the event of the debtor's insolvency. Whether the transaction gives a right to specific performance, and thus an equitable charge, depends upon the intention of the parties and what they have done in the existing circumstances. The intention may be express or inferred. It may be inferred in the following case: ${ }^{37}$

If the debtor undertakes to segregate a particular fund or asset and to pay out of that fund or asset, the inference may be drawn, in the absence of any contra indication, that the

33. Sampson v. Pattison (1842) 1 Ha. 533; Tennant v. Tranchard (1869) 4 Ch. 537; In Re Owen [1894] 3 Ch. 220.

34. Keeton \& Sheridan, Equity (1969) at 186.

35. [1979] Ch. 548, [1980] 3 W.L.R. 457 (C.A.).

36. Palmer v. Carey [1926] A.C. 703 (P.C.).

37. In Re Nanwa Gold Mines Ltd. [1955] 1 W.L.R. 1080, cited in Swiss Bank Corp. v. Lloyds Bank Ltd. supra n. 35. 
parties' intention is that the creditor should have such a proprietary interest in the segregated fund or asset as will enable him to realize out of it the amount owed to him by the debtor.

The Court extended this principle by providing that, notwithstanding the intention of the parties, if on the true construction of the contract, in the light of admissible evidence as to surrounding circumstances, the legal effect of the transaction is to give rise to an equitable charge in favour of one party over the property of the other, the absence of intention by either party to create such a charge will not defeat it. The parties must be presumed to intend the natural consequences of their acts.

The Court found on the facts that the wording of the clause was so precarious that it did not give rise to a charge in the nature of a mortgage. There were no other clear indications that the parties intended either expressly or impliedly to create an interest in the property. The Court emphasized that the precarious nature of the arrangement does not necessarily mean there is no charge. For example, the Court noted that a terminable lease would be capable of being the subject matter of a mortgage.

Finally, the Court of Appeal concluded that there was no charge other than a mortgage. In deciding that the fruits of the loan were not intended to be made available as security in the nature of a charge, the Court quoted the following passage..$^{38}$

I think there can be no doubt that where in a transaction for value both parties evince an
intention that property, existing or future, shall be made available as security for the
payment of a debt, and that the creditor shall have a present right to have it made
available, there is a charge, even though the present legal rights... can only be enforced
at some future date, and though the creditor gets no legal right of property, either
absolute or special, or any legal right to possession, but only gets a right to have the
security made available by an order of the Court.

This unanimous judgment of the Court of Appeal has important implications for equitable liens. Although the word "lien" is not used expressly, it is clear that the reasoning would be directly applicable to equitable liens which would create an interest in the property charged only where specific performance is available. Regrettably, the distinctions made by the Court between an equitable charge and an equitable mortgage are extremely vague. The Court's characterization of an equitable mortgage includes the words "transfer or charge", while the description of an equitable charge is more narrowly construed so as to include the creation of a "charge" where there is no transfer in law or in equity. The categories would be more certain if the description of the equitable mortgage referred only to a "transfer" rather than a "transfer" or a "charge".

The categorization of liens and their consequences becomes more complex with the introduction of contractual liens. Contractual liens are interpreted by the Courts in accordance with the intention of the parties as expressed in the agreement itself. ${ }^{39}$ To establish a lien by express contract, the contract must be certain. There are many authorities endorsing the creation of either a contractual common law lien or a contractual equitable

38. National Provincial and Union Bank of England v. Charnley [1924] 1 K.B. 431, cited in Swiss Bank Ltd. v. Lloyds Bank Ltd. supra n. 35.

39. Halsbury's, supra n. 9 at 223. 
lien, but text book writers cite, in addition, other authorities which treat contractual liens as an interest more in the nature of a pledge..$^{40}$ The legal status of contractual liens was clarified by the New Zealand Court of Appeal in Waitomo Wools (N.Z.) Ltd. v. Nelsons (N.Z.) Ltd."1 The respondent scoured wool for the appellant who owed \$61,257.66 for wool previously scoured and released to the appellant when the company went into receivership. At the time of the receivership, the respondent was in possession of 1,255 bales of wool and claimed a right to sell that wool and apply the proceeds against the general account in accordance with the following contractual lien provision:

12. Lien. All wool whether greasy or scoured held by the scourers for the account of a client may be retained as security for the payments of all sums which are or will be due by the said client; this lien does not cease by the transfer of the wool to another owner.

The Court noted that the right of lien, being purely contractual in nature, depends solely upon the construction of the contract term which is to be made according to its ordinary and natural meaning unless there is a sufficient reason to depart from that meaning. The all embracing terminology of the contract lead the Court to conclude that as soon as the wool was received by the respondent it became subject to a right of lien in respect of all sums due on the general account, not just present charges. In so deciding, the Court rejected the proposition that the construction of a contractual lien must be made on the basis that it is improbable or unreasonable to suppose that the parties intended to create a general lien. ${ }^{42}$ The Court did not consider other authority suggesting that particular liens are favoured by the law and are to be liberally construed. ${ }^{43}$

The primary issue faced by the Court of Appeal was whether the contractual lien was an equitable one creating a charge on the wool and void as a consequence of the failure by the respondent to register the lien under the Companies Act. The Court adopted the distinction drawn between legal and equitable liens in Snell's Principles of Equity. ${ }^{44}$ The decision by the House of Lords in Great Eastern Railway Co. v. Lord's Trustee ${ }^{45}$ was applied strictly by the Court in finding that a contractual lien with a power of sale is a possessory lien but not a charge, unless the contractual lien expressly creates a charge. Both the House of Lords and the New Zealand Court of Appeal clearly endorsed the proposition that contractual liens can be either possessory rights with or without a power of sale or equitable rights attracting registration obligations and a right to a judicial sale. The Court of Appeal described the latter right as a deduction from the right of ownership rather than a mere interference with the right to possession which is normally an incident of ownership. A charge was said to confer an interest in the property carrying a right to resort to the

40. Gladstone v. Birley supra $\mathrm{n}$. 30. Pledges are discussed in the text accompanying $\mathrm{n} .51$ et. seq.

41. [1974] 1 N.Z.L.R. 484 (C.A.).

42. Waitomo Wools (N.Z.) Ltd. v. Nelsons (N.Z.) Lid. did not apply the case of Rushford v. Hadfield (1806) 7 East 224, 103 E.R. 86.

43. Jackson v. Cummin (1839) 5 M. \& W. 342; Scarfe v. Morgan (1838) 4 M. \& W. 270.

44. Supra n. 14 at 482.

45. [1909] A.C. 109 (H.L.). 
property to satisfy an obligation secured by the charge. As a result of these authorities, a contractual lien with or without a power of sale will be considered possessory only unless the words creating the lien can be construed as creating a charge.

The Canadian Courts have not considered the decisions of the House of Lords or the Court of Appeal and have given only the most cursory attention to resolving the conceptual difficulties surrounding the legal status of contractual liens. In Ruptash v. Zawick, ${ }^{45}$ the Supreme Court of Canada decided that an agreement whereby one co-tenant promised to pay and contribute a specified portion of all costs of repairing jointly owned realty did not constitute a contractual lien or charge on the property. The respondent made this claim against the appellants, Ruptash and Lumsden, who purchased the interest of the previous co-tenant from whom the debt was owed. The Trial Judge of the Supreme Court of Alberta found that, since both appellants knew the content of a caveat filed against the land, they also had knowledge of the agreement between the previous co-tenants and failed to enquire into the expenses owing. Consequently, the respondent had a lien on the interest of the appellant for the expenditures made by the previous co-owner. This "equitable lien" was said to be granted under the authority of the Court as security for the fulfillment of a contractual obligation which was filed as a caveat and bound the subsequent owners. Thus, the Trial Judge did not depend on the contract itself as creating the lien and relied instead on the inherent jurisdiction of the Court to decree the security. American authority was cited in support of such a proposition. ${ }^{47}$ After minor variations to this judgment by the Appellant Division, the Supreme Court of Canada found that the contract did not expressly create a lien, and by implication, one must conclude that the Courts cannot impose a lien if it is not expressly created by the contract or by the operation of law. The Court concluded as follows: ${ }^{48}$

\footnotetext{
... the respondent had a contractual right to recover from William Zawick the latter's proportionate share of the moneys expended by the former on repairs ... [O]n its proper construction the contract did not create a lien or charge.
}

The Court uses the terms "lien" and "charge" disjunctively even though only an equitable lien could arise, since the appellant took possession of the property away from the respondent thus terminating any right of the latter to a contractual possessory lien against the property of the original cotenant for expenses incurred. A more accurate expression of the principle would be to treat the words "equitable lien" and "charge" as synonymous, although there may be charges other than liens and mortgages.

The Supreme Court of Canada characterized the contractual right granted in this case as a terminable right to manage and be in the possession of the property and collect the rents in return for a promise by the other cotenant to pay his share of the expenditures. The rights were terminable by either party with thirty days notice and, contrary to the view of the Court of Appeal in the Swiss Bank case, the Supreme Court of Canada concluded

46. Supra n. 11.

47. 86 Corpus Juris Secundum at 460 .

48. Supra n. 11 at 360 (S.C.C.). 
that the terminable nature of the right was inconsistent with the creation of a charge. ${ }^{49}$

The lack of express words creating a lien or charge and the termination of the respondent's possessory interest, as a result of the sale by the cotenant, made consideration of the distinctions drawn by the House of Lords between legal and equitable liens unnecessary in this case. The Supreme Court of Canada has not had an opportunity to consider the matter again. Other Canadian Courts have considered contractual liens but without reference to the conceptual clarifications made early in the century by the House of Lords or later by the New Zealand Court of Appeal.

The Ontario Court of Appeal considered a contractual lien in Bank of Montreal v. Guarantee Silk Dyeing and Finishing Company. ${ }^{\text {so }}$ The contract included the following clause:

all goods covered by this order and their appurtenances are hereby represented by (the) customer to be free from prior encumbrance and/or claim and are pledged with the company as security for the payment of all the customer's accounts now and/or hereafter due...

The Court held that the bank, which advanced funds to the Brupbacher Co., did so without knowledge of the prior contractual lien. However, the bank, by directing that goods covered by its securities were to be sent to the Guarantee Silk Co., was taken to have been aware of a common law lien on the goods themselves and to have impliedly agreed that the lien should form a charge on the goods and have priority over the bank's security. The Ontario Court of Appeal stands alone in finding that a common law lien can create a charge on the goods possessed. The true nature of a common law lien in this case is a right to maintain possession of the silk until there is remuneration for the dyeing. The Court assumes, without establishing a trade usage, that the common law lien is general rather than specific. Any sale of the silk by the dyeing company would have been a conversion. As it was, the bank consented to the sale of the silk and the proceeds were held pendente lite.

The Court went on to consider the contractual lienholder's right with respect to silk received by it before the company granted the bank a security interest in the silk. The contractual lien attached to these goods in priority to the bank's security. The interest of the dyeing company had to be equitable rather than possessory in order to rank in priority to the bank's equitable interest in the silk, although the Court did not say so expressly.

The contract term referred to a "pledge" and the Court of Appeal failed to consider the distinction between a "pledge" and an "equitable lien". In Donald v. Suckling, Blackburn J. distinguished between a lien and a pledge in the following manner: ${ }^{51}$

There is a great difference . . . between a pledge and a lien. The authorities are clear that a right of lien, properly so called, is a mere personal right of detention; and that an

49. The terminable nature of a lease over minerals would not likely defeat the right to a lien over that interest. Unlike a mere contractual right to manage property, the leasehold estate carries numerous legal rights giving this interest a much higher status in law. Thus, the terminable nature would be less significant.

50. [1935] 4 D.L.R. 483 (Ont. C.A.).

51. [1866] 1 Q.B. 585 at 612 . 
unauthorized transfer of the thing does not transfer that personal right . . . I think that both in principle and on authority, a contract such as that stated in the plea, pledging goods as a security, and giving the pledgee power in the case of default to dispose of the pledge (when accompanied by an actual delivery of the thing), does give the pledgee something beyond a mere lien; it creates in him a special property or interest in the thing $\therefore$.

This case was followed in Prete v. Lauzon and Fenson, a decision of the Appellate Division of the Ontario Supreme Court. ${ }^{52}$ The defendant held a machine as security for a debt owed by the original owner. The owner sold the machine to the plaintiff subject to the defendant's security interest with the understanding that the plaintiff would pay the defendant the debt owed. No payment schedule was agreed upon between the plaintiff and the defendant and the defendant sold the machine without giving notice to the plaintiff. The Court found the sale was a conversion, because it was undertaken without a prior demand for payment on the plaintiff to allow him to either repay the debt or default. The defendant's rights were described as an interest in the good rather than a mere possessory interest conferred by a lien. This interest has been described in other cases as a "special property" in the goods. ${ }^{33}$ The Alberta Court of Queen's Bench did not consider these authorities in deciding that a pledge was the delivery of a specific good as security for a specified debt, whereas a general lien was a right of retention of any of the debtor's goods until all debts were satisfied and, moreover, that a pledge was no different than a general lien in that it required continuous possession of the chattel and was not an assignable interest. ${ }^{54}$ The effect of these decisions was to make a pledge indistinguishable from a common law particular lien. A review of case law outside of this jurisdiction leads one to the conclusion that the pledge is more appropriately equated with the equitable lien insofar as both create an equitable interest amounting to a charge on the goods and, consequently, a right of assignment and judicial sale are attached to both interests. The primary distinction between the two forms of security is the need, in the case of a pledge, for the transfer of possession from the pledgor to the pledgee and to any assignee..$^{35}$ Absent this exchange, the pledge is not created or sustained. Constructive possession is frequently used as a device to satisfy the rule when there is no actual delivery of possession to the lienholder. ${ }^{56}$

A pledge or pawn of goods has been described generally as a bailment of goods or chattels as security for some debt or engagement. ${ }^{77}$ There is limited authority to suggest that a lien created by contract is more in the nature of pledge, ${ }^{58}$ although other Courts have treated a contractually created pledge as an equitable lien. ${ }^{59}$ The New Zealand Court of Appeal, ${ }^{\infty 0}$

52. Supra n. 28.

53. Exparte Hubbard (1886) 17 Q.B.D. 690; Donald v. Suckling supra n. 51.

54. Adanac Tire v. Sheriff (1979) 17 A.R. 147; Senft and Hicks v. Bank of Nova Scotia (1986) 69 A.R. 35 (Alta. Q.B.).

55. Ex parte Hubbard supra n. 53; Prete v. Lauzon supra n. 28.

56. Young v. Lambert (1870) L.R. 3 P.C. 142, 6 Moo. P.C. (W.S.) 406.

57. Halsbury's, supra n. 9 at 226.

58. Supra n. 30.

59. See e.g. supran. 50.

60. Supra n. 41. 
in its exhaustive analysis of liens at common law and in equity, gave only cursory attention to the category of pledges, noting the distinctions stated above as well as the fact that it is registrable as a charge. The Court did not determine when an interest is to be categorized as a pledge rather than an equitable lien. One can only conclude that the language creating the interest will usually be highly relevant along with the fact of whether or not delivery of possession has occurred. If not, the Court must treat it as an equitable lien or allow the interest to be defeated. As an analogy, there are numerous cases where the Courts have categorized what would seem to be a mere possessory lien as an equitable lien because the lienholder had sold the property, an act tantamount to conversion if the lien was possessory only. ${ }^{61}$

The contractual lien has a firm foundation in law as evidenced by the authorities in other Commonwealth countries. Its legal status in Canada is largely undetermined and one can only say that the conceptual inconsistencies between liens, pledges and mortgages are reflected in the decisions of Canadian courts to date. Before attempting to apply the existing authorities to the CAPL Operator's lien, some consideration must be given to the application of these principles specifically to an interest in land and the treatment of contractual liens by the American courts.

\section{APPLICATION OF THE PRINCIPLES TO INTERESTS IN LAND}

The CAPL Agreement grants a lien to the Operator on the interest of each Joint-Operator in the joint lands. The leasehold interest of each Joint-Operator is a profit à prendre ${ }^{62}$ or, more particularly, an incorporeal interest in land. As such, the interest of the Operator in the leases falls within the purview of the Land Titles Act, ${ }^{63}$ if the land is owned privately, or the Mines and Minerals Act ${ }^{64}$ if the land is owned by the Crown in the Right of Alberta. There is uncertainty in the classification of this lien right as possessory or equitable and as a lien, pledge or mortgage. The presumption that a contractual lien in respect of personalty is merely possessory unless the contract can be interpreted as conferring an equitable right, is presently inapplicable to an interest in land. It is debatable whether a Court today would enforce a contractual lien purporting to grant only a possessory interest in land, either by an actual deposit of title deeds or by a contractual term conferring possession on the Operator, or whether the Court would classify the interest as an equitable charge or mortgage.

One writer ${ }^{6 s}$ has traced the development of the law as it relates to a deposit of title deeds from the earlier decisions, where the deposit constituted a possessory lien, to more recent times, where that act is inevitably characterized as an equitable mortgage either with or without an ancillary right to possess the title documentation. In the eighteenth

61. Pothonier and Hodgson v. Dawson supra n. 22; Gurnell v. Gardner supra n. 26; Prete v. Lauzon supra n. 28.

62. Berkheiser v. Berkheiser [1957] S.C.R. 387.

63. R.S.A. 1980 c. L-5, as am.

64. R.S.A. 1980 c. M-15, as am.

65. Sunnucks, "Lord Thurlow's Equity or A Cuckoo in the Legal Nest", supra n. 8. 
century, there developed a practice of offering the title deeds to the lender as security for a debt. ${ }^{66}$ The title deeds were retained by the lender until the debt was satisfied. This right of retention was usually regarded as possessory only, although some Courts considered the deposit as more in the nature of a pledge, thereby attracting rights of assignment and judicial sale. The deposited deeds were described by the Courts as the "sinews of the land"67 and came to be regarded as chattels.

The Courts of Equity intervened and altered the legal significance of depositing title deeds when Lord Thurlow held, in a series of decisions, that this act created an equitable mortgage. ${ }^{68}$ The purpose of these decisions was to overcome the need for written evidence of a mortgage under the Statute of Frauds. Possession of title deeds was an act of part performance and, consequently, no writing was required.

In the nineteenth century, lenders relied extensively on the characterization of the possession of title deeds as an equitable mortgage since the legal remedies, including a right to foreclosure, were superior to the mere right of retention conferred by a possessory lien pending the payment of the debt. This development in the law was criticized by judges and lawyers alike, although it continued to be applied. Lord Eldon was particularly critical of these developments, as evidenced by the following passage: $:^{69}$

I remember, previously to Russel v. Russel, it was very much doubted, whether a mere deposit of deeds constituted an equitable mortgage, if there was no writing to manifest the purpose; resting altogether on parole; and it is quite competent to the man who put the deeds into the hands of a creditor, without reference to the debt, afterwards from favour to that creditor to say, they were deposited with him for the purpose of securing his debt; and so all the perjury that the statute meant to avoid is introduced; and the rule changed. But Lord Thurlow was of the opinion, and that is not now to be disturbed, that the fact of the adverse possession of the deeds in the person claiming the lien, and out of the other, was a fact, that entitled the Court to give an interest.

In later decisions, Lord Eldon refined the principles established by Lord Thurlow in holding that where a deposit of title deeds is accompanied by a written contract, the terms of the contract govern the purpose of the deposit and, therefore, its legal effect. ${ }^{70}$

The distinction between possessing the title deeds and having an interest in the land itself was made again in 1906 by the Court of Appeal. A bill of sale affected the title deeds to land and its validity depended on whether the bill of sale created a charge upon the land or simply upon the deeds as chattels. In holding that only the deeds as chattels were affected, Vaughan Williams L. J. stated as follows: ${ }^{71}$

Then it is said that we cannot read this instrument in this way, because the deeds so savour of realty that the assignment of this lease together with the muniments of title must have been intended to give an interest in land. That might be a very strong argument if it were a true proposition at law that documents of title cannot be severed from the land, but the decision in Barton v. Gainer is in my opinion an authority to the contrary . . . [I]t is of course well known that as a matter of fact deeds are not infrequently handed over not for the purpose of dealing with the subject matter of the deeds but for the purpose of giving the person with whom the deeds are deposited what is called a "sit upon" title.

66. Id. at 131 .

67. Id.

68. Id. at 132.

69. Exparte Coming (1803) 9 Ves. 115 at 117.

70. Supra n. 65 at 133.

71. Swanley Coal Company v. Denton [1906] 2 K.B. 873 at 878 and 879. 
At the turn of the century, it is reasonably clear that although the Courts were more inclined to accept the creation of an equitable mortgage by the deposit of title deeds, they were reluctant to deny the lender the right to possess the title deeds and that right was separate and distinct from any rights attaching to the equitable mortgage. Furthermore, the terms of a contract accompanying the deposit of the deed were essential in determining the purpose of the deposit.

In the present century, registration of interests in land, pursuant to land titles legislation, became critical in obtaining priority over other creditors. In England, this caused the Courts to consider the efficacy of asserting a separate and distinct possessory lien subsequent to losing the right to an equitable mortgage through failing to register that interest as a charge. After a series of confusing and contradictory decisions, the matter came before the Courts again in 1968 in Re Molton Finance. ${ }^{n}$ Title deeds were deposited with a memorandum stating that they were to be equitably charged with repayment of a debt. The charge was void for not being registered under the Companies Act but a claim to a possessory lien was made, although unsuccessfully. In the High Court, Pennycuick J. held that the lien on the deeds existed, without the necessity of registration, but could not be asserted independently of the mortgage, since it was destroyed with the mortgage as a result of the failure to register the latter. The Court of Appeal went much further than the High Court in rejecting the principle that a possessory lien is created on the deposit of title deeds. Lord Denning M.R. stated the following: ${ }^{73}$

\begin{abstract}
We have looked into all those authorities, and I must say I think they have no application here. It seems to me that when an equitable mortgage or charge is created by deposit of title deeds, there is an implied contract that the mortgagee or chargee may retain the title deeds until he is paid. This implied contract is part and parcel of the equitable mortgage or charge. It is not a separate legal or common law lien ... when the charge is avoided for non-registration then everything which is ancillary to it is avoided also. So this contractual right of retention is avoided too. It seems to me quite impossible to suppose that a separate lien is preserved after the charge has been avoided.
\end{abstract}

The judgment of Lord Denning ignores two centuries of case law establishing the separate existence of the mortgage and the lien and the importance of referring to the express contractual terms to determine the legal effect of depositing the deeds.

In the same year, the Chancery Division, in Capital Finance Co. Ltd. v. Stokes and Another, ${ }^{74}$ recognized the separate existence of the possessory lien. The first defendant sold land to the second defendant but retained possession of the title deeds and the property. The agreement provided in express terms for a loan by the vendor to the purchaser for a portion of the purchase price secured by a "mortgage" in favour of the vendor.

The first defendant lost in a priority contest with a subsequent debenture holder because his contractual mortgage was not registered and was, therefore, void as against other creditors. In characterizing the nature of

72. [1968] Ch. 325 (C.A.); the decision of the High Court of Chancery is unreported.

73. Id. at 332 .

74. [1968] 1 W.L.R. 1158 (Ch. D.). 
the vendor's lien on realty, the Court cited the following passage in Snell's Principles of Equity: ${ }^{75}$

As soon as a binding contract of sale is made, the vendor has a lien on the property for the purchase-money and a right to retain the property until the money is paid . . . Occasionally, however, the vendor will have no lien. If he receives all that he bargained for ... there will be no lien on the property sold.

The Court held that the first defendant, having bargained for a legal charge, being a higher interest than a lien, could not assert the lower interest when the charge was void because of non-registration. It is not clear whether the Court relied on the first defendant's physical possession of the land or his possession of the title deeds, or both, as creating the lien. It is significant that, in establishing the existence of the mortgage, the Court relied on the written contract rather than the vendor's possession of the title deeds or the land. It was not necessary for the Court to consider the potential effect of a valid possessory lien as against the subsequent equitable interest of a debenture holder over the same property. The parties agreed that if the first defendant had a vendor's lien on the date of execution, the lien would have priority over the plaintiff's charge. On first principle, it seems that such a proposition could only be asserted if the vendor's lien was an equitable interest and, therefore, usually capable of defeating an equitable interest granted later in time or, alternatively, if the debenture holder had knowledge of the possessory lien prior to taking its security. In spite of this uncertainty, the authority cited clearly related to a possessory rather than an equitable lien.

It is possible to grant possessory interest in land in a manner other than a deposit of title deeds. There are decisions of the Court of Chancery supporting the existence of a common law possessory lien on land by virtue of the vendor's right of possession. In Re Birmingham,${ }^{76}$ the Court depicted the vendor's lien as a right of the vendor to remain in possession of realty until the date of completion, when possession is given to the purchaser and the lien turns into an equitable one, capable of positive enforcement. The lien up to completion date gives the vendor the right to remain in possession and to refuse to execute the conveyance until the purchaser pays the amount presently due, although no positive action, including suit or sale, could be initiated by the vendor on the lien itself.

The Alberta Supreme Court, in Fialkowski v. Fialkowski, ${ }^{n}$ followed English authority in finding that a deposit of a duplicate certificate of title as security for a loan constituted an equitable mortgage. This principle, although subsequently applied by the Alberta Courts, has never been overturned or varied. It is not clear whether the Courts, if presented with this issue, would follow Lord Denning's reasoning in Re Molton Finance, or the numerous earlier authorities dating back to the eighteenth century supporting not only the existence of a possessory lien against an interest in land but also the need to review the contractual term creating it to determine the legal effect of the possession. The outcome of this quandary is relevant to the oil and gas industry, since Operator's typically do not

75. Supra n. 14 at 490 and 491 .

76. [1959] Ch. 523.

77. (1911) 1 W.W.R. 216, 4 Alta. L.R. 10, 19 W.L.R. 644 (Alta. S.C. T.D.). 
register the lien. Failure to register what is considered to be a registrable interest under the Land Titles Act, results in a loss of priority to other registered interests arising later in time.

If the lien clause creates an equitable lien against the lease, the lien would be registrable as an interest in land. Support for this proposition is found in Alberta Ltd. v. Dhillon, ${ }^{78}$ where the Court of Queen's Bench of Alberta held that a vendor's lien, being an equitable interest in the land, was registrable as a caveat. The Saskatchewan Court of Queen's Bench held that the common law lien of a solicitor for professional services, being only a right to possess documents affecting title, was not an interest in land and was not, therefore, registrable as a caveat. ${ }^{\text {x }}$ The Court of Queen's Bench of Saskatchewan made the same decision with respect to a real estate agent claiming a commission on the sale of land..$^{80}$

The Land Titles Act could be said to compel registration of all liens against land, whether possessory or equitable." The Act defines "mortgage" as "a charge on land created merely for securing a debt or loan" and a "mortgagor" as "the owner or transferor of land, or of any interest in land pledged as security for a debt or a loan". ${ }^{82}$ One could assert that the word "pledge" includes mere possessory rights, although a pledge has traditionally meant an equitable interest and this interpretation is especially compelling if one considers section 135.1 of the Act which provides for the transferability of the interest of a caveator, a right inconsistent with a mere possessory lien. In addition, caveats are given priority according to the date of registration,,$^{83}$ and it seems unlikely that, by registering a mere possessory lien, one could obtain priority over some other interest in the land itself.

The Mines and Minerals Act, which is applicable to Crown land, expressly recognizes the Operator's lien, but excludes it from the category of security interests which may be registered and this exclusion applies to any Operator's lien, whether possessory or equitable. ${ }^{84}$ The Act does not provide further guidance in determining how the unregistered Operator's lien is to compete for priority with other registered interests.

It is apparent that only equitable liens are registrable under the Land Titles Act while Operator's liens are never registrable under the Mines and Minerals Act. The provisions of these statutes do not assist in determining whether it is legally possible to create a possessory lien and, if so, how that possessory right would compete with other registered interests in land. Similarly, it is not clear how an equitable Operator's lien under the Mines and Minerals Act is to compete with other interests in land which are registered. In both instances, the priority issue can be resolved in one of

78. (1982) 41 A.R. 574 (Q.B.).

79. Re Registration of a Caveat (1915) 8 W.W.R. 866. (Sask. Q.B.).

80. Lewis F. Button Ltd. v. Fuglerud [1941] 3 W.W.R. 812 (Sask. D.C.).

81. Registration requirements for Crown, non-Crown land and personalty are discussed infra at Part VI.

82. Supra n. 63 at $\mathrm{s.} 1(\mathrm{p})$ and $(\mathrm{r})$.

83. Re Royal Bank and Banque d'Hochelaga; Muller v. Schwalbe (1914) 7 W.W.R. 817, 8 Alta. L.R. 125; Imperial Oil v. Conroy and Berthiaume (1954) 12 W.W.R. (N.S.) 569 (Alta. S.C.).

84. The registration rules for Crown Lands are discussed in more detail infra at Part VI. 
two ways. First, an unregistered interest could simply be inferior to a registered interest, thereby rendering the possessory lien, and the equitable lien affecting Crown land, second in priority to other interests which may be and are registered. Second, the lien could compete with registered interests in land on the basis of common law principles. Thus, the possessory lien must be first in time and the subsequent encumbrancer must have notice of the prior possessory interest for the Operator to gain priority. ${ }^{85}$ To be successful in a priority contest with a registered interest in Crown land, the equitable Operator's lien must be first in time and the subsequent encumbrancer must have knowledge of the prior Operator's lien if the subsequent encumbrance is a legal interest in the land. It is debatable whether these common law priority rules continue to have any relevance under the Alberta land titles system. The exceptions to registration are specifically stated in section 64(1) of the Land Titles Act. Certain statutory exceptions ${ }^{86}$ are not enumerated in this section, however, it is questionable whether possessory rights created by contract can constitute a further exception to what is considered by most to be a complete statutory registration system and priority scheme. In this regard, it may be appropriate to make an analogy to the law of adverse possession. ${ }^{87}$

The Mines and Minerals Act does expressly recognize the Operator's lien, although not specifically as a possessory or equitable interest. Once again, it is necessary to determine whether unregistered interests are simply inferior to registered interests or whether the registration scheme incorporates common law principles for those instances where one interest cannot be registered. A stronger argument can be made for the application of common law principles under the Mines and Minerals Act, since an Operator's lien which is equitable should compete with other registrable equitable interests on an equal footing.

The present uncertainty in the law relating to possessory liens against an interest in land could be avoided in the case of privately owned minerals by ensuring that the lien clause grants an equitable lien and by registering the lien against the title. However, there is presently no standard practice of registering the Operator's lien and, consequently, it may become necessary to assert an unregistrable possessory lien if the other elements of a claim to priority can be successfully made. The common law priority rules must be asserted if the Operator's lien, either possessory or equitable, is against Crown land and is competing with any other registered interest in the land.

\section{THE AMERICAN POSITION}

The American Courts have not adopted the distinctions made in the English law insofar as contractual liens are concerned. A lien provided for by contract is presumed to be equitable in nature if it relates to personalty or realty. The principle is succinctly stated in the following passage from Pomeroy's Equity Jurisprudence: ${ }^{88}$

. . every express executory agreement in writing, whereby the contracting party sufficiently indicates an intention to make some particular property, real or personal, or

85. Priority rules are discussed infra at Pt. VII.

86. Thomas W. Mapp, "Torrens' Elusive Title", (1978) I Alta. L. Rev. Book Series.

87. Thom's Canadian Torrens System (1962 2nd Ed.) at 177 et seg.

88. Pomeroy's Equity Jurisprudence (1941 5th Ed.), Vol. IV at 696 to 698. 
fund, therein described or identified, a security for a debt or other obligation, or whereby the party promises to convey or assign or transfer the property as security, creates an equitable lien upon the property so indicated, which is enforceable in the hands not only of the original contractor, but of his heirs, administrators, executors, voluntary assignees, and purchasers or encumbrancers with notice ... [T] [Te doctrine is clearly an application of the maxim, equity regards as done that which ought to be done.

There are many other cases, similar to the English law, where the lien arises automatically by the operation of equitable principles ${ }^{89} \mathrm{~A}$ contractual lien, it would seem, is limited to possessory rights only when the contract so provides. This is opposite to the Commonwealth tradition of limiting contractual liens, at least as they relate to personalty, to a possessory interest without some express contractual provision granting an interest in the property.

A contractual lien is granted to Operators in the 1982 standard-form Operating Agreement provided by the American Association of Petroleum Landmen ("AAPL"). The Operator is given authority and obligations similar to those of the Operator under the CAPL Agreement. The Operator's lien is provided for in the following manner: ${ }^{90}$

\section{B. Liens and Payment Defaults:}

Each Non-Operator grants to Operator a lien upon its oil and gas rights in the Contract Area, and a security interest in its share of oil and/or gas when extracted and its interest in all equipment, to secure payment of its share of expense, together with interest thereon at the rate provided in Exhibit " $C$ ". To the extent that Operator has a security interest under the Uniform Commercial Code of the State, Operator shall be entitled to exercise the rights and remedies of a secured party under the Code. The bringing of a suit and the obtaining of judgment by Operator for the secured indebtedness shall not be deemed an election of remedies or otherwise affect the lien rights or security interest as security for the payment thereof. In addition, upon default by any Non-Operator in the payment of its share of expense, Operator shall have the right, without prejudice to other rights or remedies, to collect from the purchaser the proceeds from the sale of such NonOperator's share of oil and/or gas until the amount owed by such Non-Operator, plus interest has been paid. Each purchaser shall be entitled to rely upon Operator's written statement concerning the amount of any default. Operator grants a like lien and security interest to the Non-Operators to secure payment of Operator's proportionate share of expense.

The Operator is given, in addition, a right to call on the Non-Operators for their respective portions of the debt owed by the defaulting party. ${ }^{91}$ Unlike the CAPL Agreement, there is no express assignment of the NonOperator's proceeds of production on failure to reimburse the Operator. The Non-Operators are given, in return, a lien on the interest of the Operator to secure the latter's share of the expenses.

The United States Court of Appeals considered the effect of an Operator's lien in Hill v. Field..$^{92}$ The plaintiff, who operated the oil and gas leases held by the parties in co-tenancy, sued the defendant lessee for valid expenditures incurred in the process of operations. The co-tenants made a business arrangement whereby the plaintiff would pay all expenses on the condition that the defendant would reimburse the plaintiff each month. The plaintiff told the defendant that a written operating agreement would

89. Id. at $711 \mathrm{fd}$.

90. American Association of Petroleum Landmen, "Model Form Operating Agreement: 1982" at Article VII, clause B.

91. Id.

92. 384 F. 2d 829 (U.S.C.A. Tenth Circuit, 1967). 
be prepared, but no such agreement was ever executed. The Court held that under the law of Oklahoma, a development carried out by one co-tenant pursuant to an agreement or understanding with the other co-tenant that they are to share in the burden of the development, gives the former cotenant a right to personal judgment against the other co-tenant and a valid equitable lien enforceable against the other co-tenant's proceeds of production. The lien did not attach to the proceeds of leases mortgaged to one Robinson because there was no equivalent operating relationship in existence between Robinson and the Defendant. This case clearly extends the appliction of the equitable lien beyond a contractual agreement to an "operating relationship".

Similar principles were applied in Syring v. Sartorious, ${ }^{93}$ a decision of the Court of Appeals of Ohio. The following contractual lien was granted to the Operator: ${ }^{94}$

Operator is given a first and preferred lien on the interest of each party covered by this
contract, and in the oil and gas produced and the proceeds thereof, and upon each party's
interest in material and equipment, to secure the payment of all sums due from each such
party to Operator ... Operator ... is authorized to collect from the purchaser or
purchasers of oil or gas, the proceeds accruing to the working interest ... up to the
amount owing...

The Court cited numerous cases wherein the Courts enunciated the principles from Pomeroy's Equity Jurisprudence, quoted previously. ${ }^{95}$ The Court made special reference to Ketchum v. St. Louis, ${ }^{96}$ which reviews the American and English authorities. The Court in Ketchum cited Lord Thurlow in Legard v. Hodges, ${ }^{97}$ where an agreement to pay the income from real property bound the land itself in the form of an equitable lien.

Finally, the Ohio Court of Appeals noted the modern tendency to extend the equitable lien in circumstances where, for example, unjust enrichment results from the expenses incurred by one person for the benefit of another. Williams and Meyers cite numerous cases for the proposition that the Operator has an implied right of lien on the Non-Operator's share of production. ${ }^{98}$ The authors cite what they consider to be limited authority to the contrary. The equivalent legal concept in Anglo-Canadian jurisprudence is, of course, trade usage or custom.

\section{APPLICATION OF THE PRINCIPLES TO THE CAPL OPERATOR'S LIEN}

The CAPL Agreement grants the Operator a lien on the interest of each Joint-Operator in the joint lands, production and equipment. ${ }^{99}$ The interest in the joint lands is a leasehold interest while the equipment and the oil or gas, once severed from the realty, ${ }^{100}$ are personalty. The author

93. 277 N.E. $2 d 457$ (Ohio C.A. 1971).

94. Id. at 458.

95. See text accompanying n. 88.

96. 101 U.S. 306, 25 L. Ed. 999 (S.C. 1879).

97. Supra n. 24.

98. See cases cited in Williams and Meyers, Oil and Gas Law, Vol. 2 at 571.

99. See Part I, supra.

100. Vanguard Petroleums Ltd. v. Vermont Oil and Gas Ltd. [1977] 2 W.W.R. 66 (Alta. S.C.). 
assumes that Article XV of the CAPL Agreement, which makes the interest of the parties in the joint lands, the property thereon and the equipment, one of co-tenancy, gives each party both a legal and equitable interest in such property held for the joint account. The Agreement may operate on its own to grant a legal interest to each party in, for example, equipment purchased by the Operator for the joint account. If not, the Agreement would certainly confer an equitable interest in such property. Liens can attach to either a legal or an equitable estate. ${ }^{101}$

It is not clear from the particular words of the CAPL lien ${ }^{102}$ whether it creates a possessory interest with a right of sale or an equitable interest in the joint lands, the severed oil and gas and the equipment. The general words in paragraph (a) of Article V, clause 505 grant a lien "on" the interest of each Joint-Operator in the various properties to "secure payment" of the cost and expense of operations. This general paragraph would be subject to the specific provisions following it. The Operator is given the right to invoke the remedies in sub-paragraphs (i) to (iii) after giving thirty days notice to the Joint-Operator of the default in paying or advancing funds. Sub-paragraph (iii) provides for the enforcement of the lien created by the default by taking possession of the interest of the defaulting Joint-Operator and selling the same at a private auction or sale. Paragraph (a) and sub-paragraph (iii) may both be construed as a possessory lien with a power of sale and should be so construed, at least with respect to the personalty, on the principle that a lien is possessory unless the express words of the contract create a greater interest. The combination of the leasehold interest with the interest in chattels, assuming the Operator exercises its lien rights in respect of both, makes the application of this principle less likely, unless the Courts are willing to characterize the lien on the leasehold interest as possessory as well. If the lien on the lease is considered to be equitable, then the lien on the severed minerals and equipment would likely be equitable rather than possessory, in spite of the authorities to the contrary. This would avoid the situation where the failure to register the lien on the lease as a charge or a mortgage would, nevertheless, leave the Operator in possession of the chattels with a right of sale. A Court may perhaps be persuaded that the two interests are entirely different although granted in the same clause and, therefore, the lien over the lease would be a charge while the lien over the chattels would be a right to possession with a power of sale. This interpretation would be more consistent with the decisions of the Courts of England and New Zealand. However, one must question whether the Courts would choose the much simpler American system of treating a contractual lien as an equitable one, especially considering the American case authority on the Operator's lien. In the past, Canadian Courts have warned against the extensive use of American authority which may not be applicable to our system of jurisprudence. ${ }^{103}$ The difference in the land registry system alone would warrant such a warning, without even considering the vast differ-

101. Legard v. Hodges and Re Birmingham supra n. 24.

102. See text of lien clause in Part $I$, text accompanying $n .7$ et. seq.

103. McIntosh v. Leckie (1906) 13 O.L.R. 54 at 56 in Lewis and Thompson, Canadian Oil and Gas, Vol. I, Digest of Cases at 22. 
ences between the English and American traditions in the treatment of contractual liens.

The Operator's possession of the personalty as well as the leases becomes relevant if the lien granted is a possessory lien or if the Courts consider the lien to be more in the nature of a pledge. ${ }^{104}$ Possession has been interpreted broadly by the Courts and extended to constructive possession where one party has agreed to confer possession to another at a later date. ${ }^{105}$ The question of possession is one of fact, not law..$^{106}$ If the CAPL Agreement does not confer a general right to possession on the Operator, subparagraph (iii) of the Operator's lien grants that right expressly by its reference to "taking possession" which is a component of enforcing the lien which arises on default. The wording is appropriate for arguments relating to constructive possession, although this would probably be unnecessary given what appears to be a regular industry practice of Operators being in actual physical possession of all joint property for the purpose of exploration and operations.

Other clauses in the CAPL Agreement also support the position that the Operator is granted possession of all property without taking possession as part of its lien rights. Article III, clause 301 delegates the "control and management of the exploration, development and operation of the joint lands for the joint account ..."' to the Operator, and possession could be said to be an element of control or management. Article III, clause 207, which deals with the replacement of the Operator, provides as follows:

\footnotetext{
... [T] The Operator being replaced shall deliver to the successor Operator possession of the wells being drilled or operated by the Operator pursuant to this Operating Procedure ... and of all other facilities and all funds held for the joint account, together with all production, if any, which has not theretofore been delivered in kind ...
}

This clause suggests that the Operator is put in possession of at least the wells and production therefrom, making the references in the Operator's lien superfluous with respect to these items of property. The Agreement as a whole strongly suggests that the Operator is in possession of everything held for the joint account, including the joint lands.

Possession and other lien rights are made exercisable only thirty days after the Operator has provided notice to the Joint-Operator of its failure to pay or advance the costs agreed upon [paragraph (b)]. This raises the issue of attachment and perfection of the Operator's lien rights. Clearly, the Operator must follow the procedure outlined in the clause for perfection of the lien to occur. Moreover, that perfection is only made possible by attachment of the lien on default by a Joint-Operator. On its face, paragraph (a) of clause 505 would seem to grant an immediately exercisable right of lien. This paragraph, however, should be read in conjunction with the specific provisions of sub-paragraph (iii) which provides for the enforcement of the lien created by default. Default is not specifically defined in the CAPL Agreement, but Article V, clause 502

104. It would be unlikely for the Courts to decide that the Agreement confers a pledge, given the abundance of authority existing for contractual liens and the non-existence of case law in which a pledge (constituting an equitable interest) is applied to an interest in land.

105. Re Crossman supra n. 24; Young v. Lambert supra n. 56.

106. Kinloch v. Scribner (1886) 14 S.C.R. 77 affing. 2 O.R. 265. 
provides that each Joint-Operator shall pay the Operator within thirty days of receiving the Operator's statement of account. It would, therefore, be reasonable to conclude that the lien does not attach until default, which is thirty days after the Joint-Operator has received the Statement of Account if payment has not been made. Even though the lien attaches on default, those rights are not exercisable until after thirty days notice of the default has been given to the defaulting Joint-Operator.

There is some case authority suggesting that the lien may attach immediately upon being granted, ${ }^{107}$ but the contractual clauses in these cases do not contain the same limiting words as the CAPL lien. In George Barker Ltd. v. Eynon, ${ }^{108}$ the Court of Appeal decided that the contractual rights relating to the granting of a general lien for the carriage of goods arose at the time the contract was entered into, but those rights were not exercisable until the carrier took actual possession of the goods. This finding resulted in a debenture holder being bound by the contractual lien even though possession of the goods had not been taken at the time of crystallization of the charge. The lien was granted in the ordinary course of business so the Court did not have to deal specifically with the issue of attachment, but it seems evident that a possessory lien could not attach before actual or constructive possession was acquired. There is limited authority to the contrary. ${ }^{109}$

In the writer's opinion, the Operator's lien as it is presently drafted, attaches to the various properties at the time of default if the nature of the lien is equitable. If the lien granted is possessory, it would not attach until after the Operator has given the Joint-Operator thirty days notice of the default, since the taking of possession is part of the enforcement of the lien (assuming the Operator is not already in possession). The right to take possession is only ancillary to an equitable lien and only required for the purpose of sale. The right of sale is made subject to an obligation to notify the Joint-Operator of the time and place of the sale but this would not affect attachment. The time of attachment is most relevant when considering priorities between the various parties which may be interested in the same property and, generally speaking, the earlier attachment occurs, the more secure the Operator's position will be relative to the position of other parties.

Sub-paragraph (ii) of the Operator's lien gives an immediate assignment to the Operator of the proceeds of sale of the defaulting Joint-Operator's share of production and, presumably, the Operator would be required to give notice to the purchaser who would then pay the Operator rather than the Joint-Operator or his assignee. This provision seems to supplement the contractual lien rights given to the Operator and ensures that third party purchasers do not advance money to the defaulting Joint-Operator. The absence of the assignment would not affect the right of the Operator to claim the proceeds under a possessory or an equitable lien so long as the possessory lien continues to include an express right of sale. The provision

107. See e.g., Re Crossman supra n. 24.

108. [1974] 1 All E.R. 900, [1974] 1 W.L.R. 462 (C.A.).

109. In Re Crossman supra $\mathrm{n}$. 24 , the lien attached when the right was granted rather than the date possession was taken. 
does ensure that the Operator is paid directly by the purchaser, thereby avoiding the need to bring suit against the Joint-Operator or an assignee, although a suit against the purchaser could still be necessary if the purchaser continued to pay the other party. There is some authority suggesting that a contractual right inconsistent with the lien will destroy the lien. ${ }^{110}$ This would not hinder the Operator's security if the principle can be restricted in law to the lien on the extracted oil and gas and so long as the Operator complied with any registration requirements for the assignment.

There remains the possibility of the Operator's lien being created by the operation of a custom or trade usage in the oil and gas industry which seems to be the case in the United States. ${ }^{11}$ The extensive use of the lien as evidenced by its existence in standard-form Operating Agreements would bring much support for this proposition. The authorities suggest that a contractual lien will supersede a lien arising by the operation of law or equity, ${ }^{112}$ so the trade usage could not be asserted independently of or in substitution for the contractual lien. However, this will not be the result where the contract expressly preserves the operation of the lien in equity or at common law. ${ }^{113}$ Thus, the inclusion of an express contractual lien in the CAPL Agreement will likely terminate any possibility of a general common law lien arising absent a specific reference in the clause to maintaining such a right. The Operator must be in possession of the interest of the Joint-Operator for a common law lien to arise by trade usage.

A comprehensive analysis of the AAPL lien clause ${ }^{114}$ will not be undertaken, however, it is immediately apparent that the clause is unnecessarily strongly-worded given the tendency of the American courts to classify all contractual liens as equitable. The lien includes an interest "in" the chattels and "upon" the oil and gas rights. It provides expressly for the Operator to register the interest granted pursuant to the relevant Uniform Commercial Code provisions. The AAPL lien clause, with the appropriate alterations for Alberta registration systems, would be characterized by our Courts as an equitable lien even if the English law were to be applied.

\section{REGISTRATION REQUIREMENTS IN ALBERTA}

Much consideration has been given in other jurisdictions to the registration of contractual liens and, as a general rule, equitable liens which create an interest in the property are registrable while mere possessory liens are not. ${ }^{115}$ The registration requirements in Alberta will be determined by considering the Land Titles Act and the Mines and Minerals

110. In re Bowes (1886) 33 Ch. D. 586.

111. Supra n. 98.

112. Supra n. 110; Wilde v. Radford 33 L.J. 51 (Ch.); Capital Finance Co. Ltd. v. Stokes and Another supra n. 72; Halsbury's, supra n. 9 at 223.

113. Re Birmingham supra $\mathrm{n} .24$.

114. See clause in text accompanying n. 90.

115. Great Eastern Railway Co. v. Lord's Trustee supra n. 45; Wrightson v. Mcarthur and Hutchisons (1919) Ltd., [1921] 2 K.B. 807; Prete v. Lauzon supra n. 28; Waitomo Wools (N.Z.) Ltd. v. Nelsons (N.Z.) Ltd. supra n. 41. 
Act with respect to the joint lands and the Bills of Sale Act in relation to the severed oil and gas and equipment. ${ }^{116}$

The registration requirements of a lien against the leasehold title will depend on whether that interest is characterized as possessory or equitable and whether the owner of the land is a private person or the Crown. As was stated previously, ${ }^{117}$ a possessory interest in the lease need not be registered. An equitable lien must be registered if the owner of the land to which the lease relates is a private person, but cannot be registered if the owner is the Crown because of the provisions of the Mines and Minerals Act.

As a general proposition, the Crown is not bound by liens created by statute unless the statute provides so expressly. ${ }^{118}$ This proposition is based on section 14 of the Interpretation Act, ${ }^{19}$ which provides that no enactment is binding on the Crown or affects the Crown's rights unless specifically provided for in the enactment. This provision is not applicable to liens created by contract. Crown land is bound like any other land when a lessee grants a right of lien, either possessory or equitable, against its interest.

The Mines and Minerals Act applies to any interest in Crown land. Section 139.1(1) of the Act expressly recognizes and defines the Operator's lien in the following manner: $:^{120}$

(b) "Operator's lien" means an interest in or charge on collateral if

i. the interest or charge arises under a contract to which an owner of the collateral is a party,

ii. the contract provides for the conduct by a person (in this clause called "the operator") other than that owner, of exploration, mining, drilling, development, production, processing or abandonment operations in respect of the mineral to which rights are granted by the agreement concerned,

iii. the contract requires that owner to make payments to the operator to cover all or part of the advances made by the operator in respect of the cost of those operations, and

iv. the interest or charge secures the payments referred to in subclause (iii).

"Collateral" is defined as the interest of the lessee or an interest in an agreement derived directly or indirectly from the lease. ${ }^{121}$ Section $140(1)$ provides for the registration of a security interest, which is given priority by date of registration rather than execution. ${ }^{122}$ Section 139.1(f) states that the Operator's lien is not a security interest and, therefore, constitutes an unregistrable interest which would compete with registered interests on the basis of common law principles unless the effect of the statute is to give the lien a lower status. The Act recognizes the Operator's lien insofar as it is "an interest in or charge on" the joint lands and this description would apply to an equitable lien rather than a possessory lien. Thus, it would seem

116. Supra nn. 63 and 64; Bills of Sale of Act, R.S.A. 1980, c. B-5 as am.

117. See Part III, supra.

118. Kardinal Homes Ltd. v. Alberta Housing Corporation (1979) 8 Alta. L.R. 56; George Wimpey Can. Ltd. v. Peelton Hills Ltd. (1981) 31 O.R. (2d) 563; affd. (1982) 35 O.R. (2d) 787; leave to appeal to S.C.C. refused (1982) 23 R.P.R. 123; Saskatchewan Bd. of Education v. Saskatchewan [1981] 6 W.W.R. 503 (Q.B.); B.A.C.M. Ltd. v. Parkland Contracting Ltd. (1971) 18 D.L.R. (3d) 377 (Sask. Q.B.).

119. R.S.A. 1980 c. I-7, as am.

120. Supra n. 64 at subparas. 139.1 (b)(i) to (iv).

121. Id. at para. 139.1(1)(a).

122. Id. at subs. $140(4)$. 
that a possessory lien, being even a lesser right and not an interest in land, would similarly not be registrable.

A lien on a lease of privately owned land must be registered pursuant to the requirements of the Land Titles Act if the lien is equitable and thereby operating as a charge or a mortgage. The lien may be filed as a caveat if the requirements of Section 130 are fulfilled. Most importantly, the person must be "claiming to be interested in the land for which a certificate of title has been issued or in a mortgage or encumbrance relating to that land". The caveat operates against the interest or estate of "any person", which would be the leasehold estate of the Joint-Operators. Section 131 provides that the caveat must state the nature of the interest claimed and the ground upon which the claim is founded. Perhaps these requirements can be met by filing the Operating Agreement in its entirety as an unregistered instrument, however, case authority in other jurisdictions suggests that to be protected the particular interest must be specifically referred to in the caveat. ${ }^{123}$ As was discussed previously, ${ }^{124}$ the reference to "interest in land" makes the registration of a caveat applicable only to an equitable lien. A possessory lien would be encompassed by the Land Titles Act only if it is regarded as more in the nature of a mortgage or charge. Moreover, this analysis is based on the assumption that the possessory lien is a valid interest even though it is not made an express exception to section 64(1) of the Act which excuses registration of certain interests.

In summary, a possessory or equitable lien is not registrable as a security interest under the Mines and Minerals Act, although it is a valid and enforceable interest against the Crown. An equitable lien must be registered as a caveat under the Land Titles Act, but a mere possessory lien would not be registrable.

The equipment and the severed oil and gas are personalty and the relevant legislation for the registration requirements is the Alberta Bills of Sale Act. ${ }^{125}$ This Act provides for the registration of a mortgage, which is defined as: ${ }^{126}$

i. an assignment, transfer, conveyance, declaration of trust without transfer or other assurance of chattels intended to operate as a mortgage or a pledge of chattels,

ii. a power or authority or licence to take possession of chattels as security, and

iii. an agreement, whether intended or not to be followed by the execution of any other instrument, by which a right in equity to a charge or security on any chattels is conferred.

A bill of sale is the document evidencing the mortgage. On the express words of this section, the Operator's lien would fall within sub-paragraph (ii) or (iii), assuming it is not a pledge. The Act appears to cover a possessory lien by virtue of sub-paragraph (ii). Section 2(1) makes a mortgage not accompanied by "an immediate delivery" and "actual and

123. Powers v. Walter [1981] 5 W.W.R. 169 (Sask. C.A.). In Zellers Ltd. v. Calford Properties Ltd. [1972] 2 W.W.R. 342 (Alta. S.C.), a caveat claiming an interest under a lease was sufficient to protect all of the caveator's interests as provided for in the lease. The Zellers case was distinguished by the Saskatchewan Court of Appeal in the Powers case.

124. See part III, supra.

125. Supra n. 116.

126. Id. at subs. 1(i). 
continued change of possession" void as against creditors and/or subsequent purchasers or mortgagees claiming in good faith and for valuable consideration. The Operator is not required to register the lien if delivery of the chattels occurs as soon as is reasonably practicable. ${ }^{127}$ The lien clause gives the Operator a right to take possession of the chattels thirty days after the Joint-Operator is notified about the default and, presumably, an Operator would be in possession of the equipment and the extracted oil and gas in any event by virtue of his actual physical control over operations or the control granted to him by the CAPL Agreement. Thus, a mere possessory lien will never require registration. If the lien is equitable and for some reason the Operator is out of possession after the lien attaches to the chattels, the Operator's interest would be defeated unless possession was retaken before the intervention of competing interests by third parties. ${ }^{128}$ If the Operator is out of possession, a debenture holder's floating charge, registered subsequent to the attachment of the lien but before its registration, would take priority over the lien providing the debenture holder was without knowledge. The debenture holder is a subsequent mortgagee under section 2(1). ${ }^{129}$ This section takes away the rights of an unregistered mortgagee, but no additional rights are conferred. Thus, any competition between a registered equitable lien and a subsequent fixed charge debenture over equipment, registrable under the Alberta Business Corporations Act, ${ }^{130}$ would be governed by common law principles. ${ }^{131}$

It is important to note the special registration requirements for "itinerant machines" which includes oil well drilling equipment. ${ }^{132}$ The normal time limit for registration under the Bills of Sale Act is thirty days from the date of execution in the Central Registry, whereas the time limit for "itinerant machines" is twenty-one days in the Vehicle Registry. If itinerant machines and other chattels are included in the same bill of sale, registration in both Vehicle and Central Registry is required.

In summary, an equitable lien must be registered pursuant to the Bills of Sale Act if the Operator is or expects to be out of possession. It is necessary to register a mere possessory lien pursuant to section 1(i)(ii), but this registration would not confer any rights on the Operator, who would lose the common law lien rights if out of possession. Registration of the lien pursuant to either the Land Titles Act or the Bills of Sale Act could not effectively be made before the lien is created by the default of the JointOperator or by the taking of possession thirty days after notice of the default is given to the Joint-Operator if the lien is possessory.

127. Re Funduk and Horncastle (1973) 39 D.L.R. (3d) 94 (C.A.); Royal Bank of Canada v. College Mercury Sales Ltd. [1977] 1 W.W.R. 645, 72 D.L.R. (3d) 609, 2 A.R. 368 (C.A.); reversing [1976] 3 W.W.R. 167; Humphrey et al. v. Hickey et al. [1972] 3 W.W.R. 389 (Alta. S.C.-A.D.); T. \& C. Truck Service and Welding Ltd. v. Henning (1981) 39 C.B.R. (N.S.) 59, 14 B.L.R. 220, 30 A.R. 164 (Q.B.).

128. Bills of Sale Act, supra n. 116 at s. 14.

129. Sperry New Holland Division of Sperry Inc. v. Central Farm Supply (Rycroft) Ltd. (1982) 41 A.R. 114, affd. 23 Alta. L.R. (2d) 21, 41 A.R. 104 (C.A.).

130. S.A. 1981 , c. B-15 as am.

131. Priority rules are discussed in Part IV.

132. Bills of Sale Act, supra n. 116 at subss. 1(h), 5(1) and 9(1). 


\section{PRIORITY ISSUES}

The choice between creating an equitable lien or a possessory lien when drafting the lien clause will depend primarily on issues of priority between the Operator's lien and other security, usually a floating or fixed charge debenture. The debenture could be granted by the defaulting JointOperator either before or after the creation of the lien and may relate to the joint lands, production and/or the equipment. It is important to remember that, under the CAPL Agreement, the lien is not created until the JointOperator defaults in a payment obligation and the date of default will be the relevant date in determining the priority between an equitable lien and some other security. If the lien is possessory, the relevant date will be the date possession is actually taken, whether that means thirty days after notice of the default is given to the Joint-Operator as provided in subparagraph (iii) of the lien clause or at the time of default if the Operator is actually in possession of the property at the commencement of operations. The writer will only introduce the priority issue, since any exhaustive consideration of priority contests depends upon the particular facts at hand and is, in any event, beyond the scope of this paper.

The most common priority contest will be between the Operator's lien and a debenture with a fixed or floating charge or both. Debentures are registered pursuant to the Business Corporations Act with respect to personalty and the Land Titles Act with respect to interests in land. The Operator's lien over the equipment and the severed oil and gas must compete with the interest of the debenture holder on the basis of common law principles rather than a statutory priority scheme, since the lien is registered under a different statute. ${ }^{133}$ The priority scheme within the Land Titles Act would apply to contests between an equitable lien on the leasehold interest and a charge on the same interest under a debenture. If the lien against the lease is possessory, these statutory priority rules are not applicable and common law principles of priority must be resorted to. As was discussed previously, ${ }^{134}$ a possessory lien against an interest in land will only be possible in law if the Land Titles system of registration can be said to contemplate the existence of an interest that does not fall within the statutory scheme.

The Joint-Operators may secure funds before the Operating Agreement is made. The security offered may include either a fixed or a floating charge on the interest of the Joint-Operator in the lease and equipment, and a floating charge on after-acquired property, including equipment bought for the joint account and extracted oil or gas. A fixed charge, being a legal charge, will always defeat a subsequent equitable or possessory lien, on the principle that equity follows the law. ${ }^{135} \mathrm{~A}$ possessory interest is less than an equitable interest and, therefore, would also be defeated. The floating charge debenture carries with it an implied licence for the Joint-Operator to grant other security on the same items of property in the ordinary course of business. ${ }^{136}$ Thus, the owner can grant the Operator its security interest

133. See Part V, supra.

134. See Part III, supra.

135. Halsbury's Laws of England (4th Ed.) Vol. 16 at 884.

136. Brunton v. Electrical Engineering Corporation [1982] $1 \mathrm{Ch} .434$. 
in the property before crystallization of the floating charge. A negative pledge aimed at preventing subsequent charges from taking priority can not take away the owner's implied authority to deal with the property, although it may affect the priority among competing interests. ${ }^{137}$ Consequently, an Operator's lien, assuming it is granted in the ordinary course of business, may arise regardless of the negative pledge, either by the operation of law if there is a general trade usage, or by a contractual possessory or equitable lien. The Operator's priority will be lost as a result of the negative pledge only if the Operator had knowledge of the negative pledge and the lien granted is an equitable lien, assuming the negative pledge makes reference to the creation of a "charge", which will normally be the case. A common law possessory lien is not a charge and, consequently, prior notice of the negative pledge is irrelevant. ${ }^{138}$ These principles will apply even if crystallization occurs before the lien attaches to the property, so long as the contractual right to the lien, although not exercisable, arises prior to that crystallization. ${ }^{139}$ If the subsequent Operator's lien is not considered to be in the ordinary course of business, a fixed equitable charge will still defeat a prior floating charge, so long as the Operator did not have notice of the floating charge ${ }^{140}$ In this circumstance, a subsequent equitable lien would take priority over a prior floating charge so long as crystallization has not occurred. A subsequent possessory lien would be defeated by a prior floating charge, since the charge is an interest in the property.

A priority contest may arise between a prior contractual lien and a subsequent debenture with a fixed or floating charge or both. The fixed charge could be granted by the owner against any combination of the lease, production and equipment. This will be a legal interest in the land and equipment if the agreement gives the owner this interest or if crosstransfers are executed by the co-owners. It will be an equitable interest if the Operating Agreement does not give the owner a legal interest in the realty and existing equipment, or if after-acquired property, such as the severed oil and gas and equipment, are included. The floating charge could relate to any of the above properties and would be equitable before and after crystallization in respect of future property, but legal in respect of the relevant properties held at the time the floating charge was first granted..$^{141}$

As a general rule, a prior possessory lien will be defeated by a subsequent charge, either equitable or legal, because the interest of the lienholder is possessory only with no interest in the property. ${ }^{142}$ The Operator's interest prevails only if the property possessed is sold pursuant to the contractual right of sale before the debenture is executed or, perhaps, if the debenture holder had knowledge of the possessory lien prior to executing the debenture. The latter proposition is taken from the principles relating to

137. Id.

138. Id.

139. Supra n. 108.

140. L.C.B. Gower, Modern Company Law (1979 4th Ed.) at 474.

141. Robbie \& Co. v. Witney Warehouse Co. [1963] 3 ALL E.R. 613 at 621 (C.A.).

142. H.G. Hanbury and R.H. Maudsley, Hanbury and Maudsley, Modern Equity (1981 11th Ed.) at 754 and 755 . 
equitable interests, whereby the subsequent legal charge holder loses priority by having knowledge of the prior equitable charge. Presumably, the same principle is applicable to subsequent equitable or legal debenture holders having knowledge of a prior possessory lien. Some support for this proposition is found in Bank of Montreal v. Guarantee Silk Dyeing, ${ }^{143}$ where the Ontario Court of Appeal held that the bank, by sending silk to the company to be dyed, must be taken to have been aware that the dyeing company would have a common law lien on the goods, and it follows that the bank impliedly agreed that the common law lien would form a charge on the silk which would take priority over the bank's prior mortgage. The Court also implied that the bank was not bound by the contractual lien because it had no knowledge of its existence. The common law lien would be possessory only, even though the Court referred to it as a charge. In its entirety, the decision supports the proposition that knowledge of a possessory interest may defeat what appears to be a better claim to priority, even though on the facts of this case, the possessory interest was subsequent in time to the mortgage.

An equitable lien on chattels, even without registration where the Operator is in possession, will prevail over the equitable interest of the debenture holder in those same chattels on the principle that the first equity prevails. ${ }^{144}$ The lien, as it is presently written, attaches only after the default of the Joint-Operator. Thus, for this analysis to be applicable, the debenture would have to be executed after default and attachment. If a fixed charge debenture is executed before attachment occurs, the debenture would take priority on the same principle. The priority of the first equity is prima facie only and subject to displacement by those acts or omissions of the holder of the equitable interest which have been found by the Courts to defeat the prima facie priority. ${ }^{145}$ If the Agreement's provision for an equitable assignment of the extracted oil and gas destroys the equitable lien, priority between assignees would be determined by who gave the earliest notice to the purchaser.

If the subsequent charge is fixed and legal, it will defeat a prior equitable lien unless the debenture holder had actual or constructive knowledge of the prior lien. Constructive knowledge could be asserted in the oil and gas industry since banks usually know the extensive use of the Operator's lien, even if there is no specific knowledge of the lien clause in any particular case.

An equitable lien on the owner's interest in the joint lands, if registered pursuant to the Land Titles Act as a caveat, would take priority only if registered prior in time to the debenture. A possessory lien on the leases would compete with a debenture on the same basic principles applicable to personalty, assuming that those principles are still relevant under the present registration system.

143. Supra n. 50.

144. Supra n. 141.

145. Rice v. Rice (1853) L. Drew 73; 61 E.R. 646 provides the foundation for another line of authority giving priority to the equity first in time only if the two equities are in all other respects equal. For a discussion on this issue see P. Schmidt and W. Bonney, "Title Problems Concerning Unregistered and Unregistrable Interests in Oil and Gas Properties" (1971) IX Alta. L. Rev. 559. 
The outcome of a priority contest between an Operator's lien and a debenture would depend on the characterization of the lien as possessory or equitable. It would be necessary to assert a possessory lien, alleging that a subsequent debenture holder had actual or constructive knowledge of the prior possessory lien, if the lien had not been registered against the leasehold title. Changes to the drafting of the standard lien clause must reflect the foreseeable priority contests between the Operator and third parties. The nature of the interest conferred by the contractual lien and the time of attachment are the most relevant factors in making drafting decisions.

\section{SECTION 177 SECURITY}

The Bank Act ${ }^{146}$ confers the following rights:

177(1) A bank may lend money and make advances on the security of any or all of the following:

(a) hydrocarbons or minerals in, under or on the ground, in place or in storage,

(b) the rights, licences or permits of any person to obtain and remove any such hydrocarbons or minerals and to enter on, occupy and use lands from or on which any of such hydrocarbons or minerals are or may be extracted, mined or produced,

(c) the estate or interest of any person in or to any such hydrocarbons or minerals, rights, licences, permits and lands whether the estate or interest is entire or partial, and

(d) the equipment and casing used or to be used in extracting, mining or producing or seeking to extract, mine or produce, and storing any such, hydrocarbons or minerals,

or of any rights or interests in or to any of the foregoing whether the security be taken from the borrower or from a guarantor of the liability of the borrower or from any other person.

Security in these properties may be granted to the bank by the "owner" at the time of delivery of the instrument creating the security or at any time thereafter. ${ }^{147}$ The bank is given a statutory right on non-payment of a loan or advance or failure to protect or preserve the property, to "take possession of, seize, care for, maintain, use, operate and ... sell, the property covered by the security . . "148 Most authors agree that the statute confers a fixed charge. ${ }^{149}$ Priority is granted to the bank over all rights subsequently acquired "in, on or in respect of" the property. ${ }^{150}$ These words would cover a possessory or equitable lien. Subsection $177(8)$ restricts this priority, where the subsequent right is registrable, to those instances where the prior section 177 security is registered in the appropriate registry before the registration of the subsequent interest.

Up to the present time, there has been no judicial consideration of section 177 . Section 179 has a similar statutory priority clause for security granted pursuant to section 178 of the Bank Act and was considered in

146. Banks and Banking Law Revision Act, S.C. 1980-81-82-83, c. 40, subs. 177(1).

147. Id. subs. $177(2)$.

148. Id. subs. 177(3).

149. F.R. Foran and R.W. Block, "Enforcement of Oil and Gas Related Security", (1986) Coping with Tough Times in the Oil Patch, a seminar sponsored by the Legal Education Society of Alberta.

150. Id. subs. $177(7)$. 
Bank of Montreal v. Guarantee Silk Dyeing, ${ }^{151}$ where the Ontario Court of Appeal held that an equitable lien granted prior in time takes priority over a subsequent security granted to a bank under section 178 (previously section 88), on the principle that the first equity prevails. Section 178 of the Bank Act was said to confer on the bank only such right and title to the goods, wares and merchandise as was then held by the person giving the security. Thus a prior (equitable) contractual lien can only be defeated by section 178 security if the Joint-Operator gives a legal interest in the specified properties to the bank, which must take the interest without notice of the prior equitable lien. In this case, the bank also directed the Company to dye other silk after the bank's security was perfected. The contractual lien had no priority because the bank, having no knowledge of the lien, did not assume an obligation to pay for the dyeing or agree to give the contractual lien priority. The bank was considered to be aware of the defendant's right to a common law lien, arising by the operation of law, because it directed the defendant to dye the silk. The common law lien formed a charge on the goods and the bank impliedly agreed that the charge had priority over the bank's security. In fact, the common law lien is not a charge on the property, so it is questionable whether the Court would have made the same decision having first noted that the lien was possessory only. The decision is, nevertheless, relevant for the importance placed on the bank's knowledge of other interests as a factor defeating the section 178 security. Moreover, the decision demonstrates that the Courts will be incorporating common law principles into the statutory rules when resolving priority disputes. These principles will likely be applicable to section 177 security, given the similarity in the rules governing priority.

Section 177 compels registration of the bank's security in accordance with the relevant provincial schemes. Assuming the security is a fixed charge, this would include the Land Titles Act and the Mines and Minerals Act for the registration of security against the leasehold interest of a JointOperator. The priority rules within the Land Titles Act would apply to any lien registrable under that Act. As was discussed previously, Operator's liens are not registrable under the Mines and Minerals Act, so common law principles would govern issues of priority between the lien and section 177 security unless the right of lien is simply inferior to registrable interests. The bank's security over personalty would be registrable under the Bills of Sale Act, assuming the security is not a debenture, but this statute does not affect priorities provided that the party out of possession complies fully with the registration requirements.

If the bank achieves priority, an obligation is imposed on it by subsection 177(4) to provide surplus proceeds, if any, to the person entitled thereto including, of course, the Operator.

\section{BUILDERS' LIEN LEGISLATION}

At one time, the CAPL Agreement provided expressly that the "Managing Operator shall have the right to enforce payment thereof . . . in the manner in which mechanics' liens are enforced under the applicable 
statutes". ${ }^{152}$ Since then, amendments to the Builders' Lien Act ${ }^{153}$ have made this statute inapplicable to security interests in property for the purpose of securing a general debt, especially the concept of completion and the holdback provision for the creation of a major lien fund. At least one author in the United States has suggested that the Operator would be able to register a contractual lien pursuant to the local Mechanics' Lien legislation. ${ }^{154}$ The existing Alberta legislation already gives a statutory lien to contractors and sub-contractors who provide materials and services to the Operator. There would be several advantages to amending the Builders' Lien Act to make it applicable to the Operator's lien. First, the lien could be perfected by completing one registration for both the real and personal interests, assuming the equipment is included as being appurtenant to the land. ${ }^{135}$ The statute provides that an estate or interest in the land attaches to the minerals. ${ }^{156}$ Second, the legislation grants an express right to register a lien on Crown land under the Mines and Minerals Act. ${ }^{157}$ Finally, attachment would occur when the work is begun or the first material is furnished by the Operator. ${ }^{158}$ Thus, registration could be delayed until actual default, but the rights of the lien holder would relate back to the commencement of the Operator's duties.

\section{$X$. THE JOINT-OPERATOR'S LIEN}

Article V, clause 506 of the CAPL Agreement provides that when JointOperators contribute to the payment of the defaulting Joint-Operator's obligations they are subrogated to the Operator's rights under clause 505. The AAPL Agreement has a similar subrogation clause and a separate right of lien to secure payment of the Operator's proportionate share of the expenses. In order for the Joint-Operator's lien rights to be effective at law, an equitable lien must be created by the Agreement, since the JointOperator is not given possession of the property by the general terms of the Operating Agreement and the Operator would have taken possession pursuant to subparagraph (iii) of clause 505 , if possession was not already conferred by the Agreement, to perfect its own possessory lien. The Operator and the Joint-Operator, exercising its right of subrogation, cannot simultaneously possess the property. An equitable lien would not require possession and, presumably, the time of attachment would be the same as for the Operator. The Joint-Operator would not be required to register the lien separately from the Operator.

152. Bartlett, "Rights and Remedies of an Operator" (1972) X Alta. L.Rev., citing Lewis and Thompson, Canadian Oil and Gas, Form B4(b) at Clause 10.

153. R.S.A. 1980 , C. B-12, as am.

154. Weidman, "Oil and Gas Operator's Liens in Bankruptcy: The Model Form Operating Agreement Versus The Trustee In Bankruptcy's Avoiding Powers" (1984) 37 Okla. L. Rev. at 141.

155. In MacFarland v. Greenbank [1939] 1 W.W.R. 572, 2 D.L.R. 386 (Alta. S.C.A.D.) equipment was considered appurtenant to the well although not annexed to the realty.

156. Supra n. 153 , subs. $4(3)$.

157. Id. subs. $26(5)$.

158. Id. s. 8. 


\section{CONCLUSION}

The present legal status of the Operator's lien is largely undetermined in Canada. If our Courts follow the traditional English principles, the CAPL Operator's lien, as it is presently drafted, could confer either a possessory lien with a power of sale or an equitable lien. The present wording of the clause, along with the express right to sell the property, increases the possibility that the interest will be characterized as possessory only. If it is not presently possible to confer a contractual right to possess land, the clause could still confer a charge or mortgage on the joint lands and a possessory lien on the severed oil and gas and equipment. If the Agreement confers an equitable lien on all items of property, a failure to register under the relevant legislation will make the lien void as against certain third parties.

Any changes to the existing CAPL Operator's lien should only be made after careful consideration of such issues as attachment of the lien and priorities between the lien and other competing interests. As a general statement, the equitable lien seems more certain, given the present American jurisprudence relating to contractual liens and the legal uncertainty surrounding the status of a possessory lien on an interest in land. Moreover, an equitable interest in the properties usually provides the Operator with a more secure interest when competing for priority with a third party. The adoption of wording similar to the AAPL Operator's lien would likely create this equitable interest, but this change, if it is to occur, must be accompanied by a routine industry practice of compliance with the necessary registration requirements. 